\title{
O NASCIMENTO DO DIREITO À ALTERIDADE NA CIDADE
}

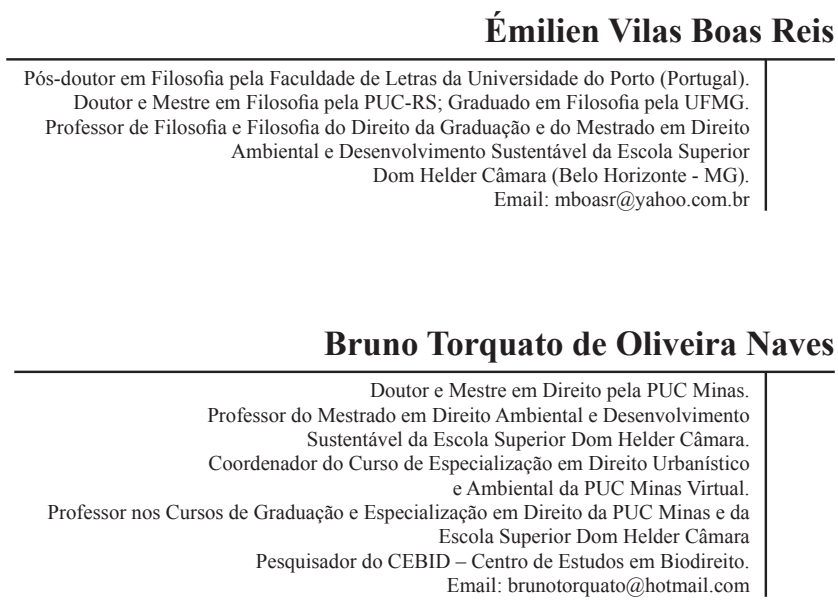

\section{RESUMO}

Com a Reforma Protestante e as grandes navegações, a consideração com o outro e o diferente passa por alterações, especialmente, frente aos considerados infiéis e aos nativos do Novo Mundo. Por outro lado, no século XVI, a Península Ibérica vivia a Era de Ouro, com o renascimento da Escolástica e o florescimento de importantes universidades jurídicas, com acentuado desenvolvimento da Ciência do Direito. O dominicano espanhol Francisco de Vitória é um expoente desses movimentos filosófico e jurídico. Este artigo objetiva compreender a contribuição de Vitória para o desenvolvimento da relação com os índios e, por consequência, para a reelaboração da alteridade. Por meio de pesquisa bibliográfica e método qualitativo, buscaram-se nos escritos de Vitória e nos contextos histórico, filosófico, teológico e jurídico, os elementos necessários para a reconstrução de sua concepção acerca do direito natural e para a verificação da possibilidade de se reconhecer, em relação aos índios, a racionalidade e o direito de domínio sobre suas terras. O projeto de construção dos direitos humanos está presente em Vitória, na defesa da universalidade da razão 
para todos os seres humanos e no reconhecimento do direito dos índios a não serem expropriados. Com isso, Vitória amplia a noção ética de alteridade vigente à época.

Palavras-chave: alteridade; índios; direitos humanos; direito natural; Francisco de Vitória.

\title{
THE BIRTH OF THE RIGHT TO ALTERITY IN THE CITY
}

The right of indigenous in Francisco de Vitoria

\begin{abstract}
With the Protestant Reform and the great navigations, the consideration about the other and with the different one, goes through changes, especially against the ones considered infidels and the natives of the New World. On the other hand, in the sixteenth century, the Iberian Peninsula lived the Golden Age, with the rebirth of Scholasticism and the flourishing of important juridical universities, with a marked development of Law Science. The Spanish Dominican Francisco de Vitoria is an exponent of these philosophical and juridical movements. This article aims to understand the contribution of Vitoria to the development of the relationship with the indigenous and, consequently, to the reworking of alterity. By means of bibliographical research and qualitative method, they searched in the writings of Vitoria and in his historical, philosophical, theological and juridical contexts. the elements of reconstruction of his concept about natural law and to see the possibility of recognizing the rationality of the indigenous and the property right over their lands. The project of human rights construction is present in Vitoria, in the defense of the universality of reason to all human beings and in the recognition of the right of the indigenous not to be expropriated. Thus, Vitoria expands the ethical notion of alterity present at that time.
\end{abstract}

Keywords: alterity; indigenous; human rights; natural law; Francisco de Vitoria. 


\section{INTRODUÇÃO}

De certa forma, o mundo europeu era, até à época do descobrimento da América, uma unidade. Esta concepção irá mudar, principalmente, a partir do século XV, com a Reforma Protestante e as grandes navegações. Com Lutero, a religião cristã se fragmenta em inúmeras denominações e, por conseguinte, estas se espalham por toda a Europa. Para completar a divisão, algumas décadas depois, as descobertas de outras terras, povos e culturas irão fazer com que os europeus questionem ainda mais essa unidade na Europa.

No meio dessa efervescência histórica, a pergunta pelo "outro" torna-se uma questão fundamental. O europeu, ao se deparar com o aparentemente outro radical, terá que pensar não apenas sobre o diferente, mas sobre sua própria situação no mundo e sua humanidade.

O século XVI, período em que tais questões serão mais bem-elaboradas, é a ocasião em que há uma redescoberta da Escolástica em Portugal e Espanha. Curioso é que tais países serão protagonistas na época das navegações. Muitos de seus teóricos utilizaram o arcabouço escolástico, a própria originalidade e o contexto histórico para refletirem sobre as consequências dos acontecimentos. Uma das implicações é a reflexão sobre a alteridade. Por isso, tais autores podem ser denominados de precursores da alteridade em sentido prático, já que o momento foi condição para isso.

A cidade é o local por excelência da alteridade, propiciando o uso de um espaço comum que deve levar em consideração a diversidade. O texto em questão tem a pretensão de trazer para a reflexão da alteridade na cidade o dominicano espanhol Francisco de Vitória, que pode ser considerado um dos primeiros pensadores a refletir como a diferença poderia conviver em um espaço comum.

O objetivo central do artigo é compreender a contribuição de Vitória para o desenvolvimento da relação com os índios e, por consequência, para a reelaboração da alteridade. Esse intento é fundamental para a compreensão do nascimento dos direitos humanos e de sua característica mais famosa - a universalidade -, bem como para a compreensão da alteridade na cidade, espaço de convivência revalorizado com a Modernidade.

Por meio de pesquisa bibliográfica e método qualitativo, buscam-se nos escritos do próprio Francisco de Vitória e nos contextos histórico, filosófico, teológico e jurídico, os elementos para reconstrução de sua concepção acerca do direito natural e para verificação da possibilidade de 
se reconhecer aos índios a racionalidade e o direito de domínio sobre as terras do Novo Mundo.

Inicialmente, será feita a contextualização política do período histórico - o século XVI. Far-se-á necessário caracterizar a segunda Escolástica e as consequências dos descobrimentos, oriundos das grandes navegações. Em seguida, ver-se-á como o surgimento do índio, "o outro" por excelência, proporcionará debates a respeito da alteridade. Na sequência, será abordado o contexto jurídico, em que se pretende localizar o pensamento de Vitória na Ciência Jurídica da época. Passa-se, então, à análise das questões da alteridade e dos direitos humanos. Por uma escolha metodológica, três textos de Francisco de Vitória serão analisados com esse viés. A ideia principal é poder demonstrar como a reflexão sobre a alteridade depende do contato com o totalmente diferente e como desse contato nascem os direitos humanos e sua aspiração à universalidade.

\section{A SEGUNDA ESCOLÁSTICA E A ERA DOS DESCOBRIMEN- TOS}

A segunda Escolástica foi um movimento intelectual de reaproximação no século XVI da Escolástica, pensamento este ocorrido entre os séculos XII e XIV. Sua criação e consolidação ocorrerão principalmente na Península Ibérica. O contexto cultural foi imprescindível para que novas reflexões surgissem, primeiro, na Europa e, depois, no Novo Mundo (América). Tomás de Aquino (1225-1274) torna-se a principal referência deste período, sendo comentado por diversos autores. Entretanto, a partir desta influência, um pensamento original surgirá desta situação. A respeito deste período, de acordo com De Boni:

Dois desafios estão por trás de seu brilho: a consciência da necessidade de repensar a fé cristã ante os problemas dos novos tempos, tais como a Reforma e a Filosofia Moderna, e os descobrimentos marítimos, que juntos trouxeram questionamentos jamais colocados anteriormente. É característico dessa época o fato de a obra a ser comentada nas cátedras de teologia não ser mais o Livro das Sentenças de Pedro Lombardo e sim a Suma Teológica de Tomás de Aquino. Nos primeiros anos do século XVI, o dominicano italiano Tomás de Vio Caietano comentou a Suma Teológica e seu confrade Francisco de Silvestre de Ferrara, a Suma Contra os Gentios (esses comentários foram anexados às respectivas obras do Aquinate na edição crítica iniciada no século XIX). Poucos anos depois, o espanhol Francisco de Vitoria, também 
dominicano, comentou igualmente a Suma Teológica. Por esse caminho seguiu-se, então, a eles, uma plêiade de teólogos, filósofos e juristas, composta principalmente de dominicanos e jesuítas (estes recém-fundados). (DE BONI, 2009, p. 5).

Dentro deste contexto, a Escola de Salamanca será fundamental para a segunda Escolástica: "Ugualmente si parla di una Scuola di Salamanca, intendendo così quei teologi spagnoli che utilizzarono i materiali della tradizione tomista per comprendere i problemi sollevati dalla scoperta dell'America". (SCATTOLA, 2009, p. 53). A Universidade de Salamanca é anterior à segunda Escolástica. Foi estabelecida por Afonso IX, entre 1218 e 1220. Em 1255, Alexandre IV concedeu-lhe os direitos das grandes universidades europeias. Na Renascença, Salamanca tornou-se bastante reconhecida devido aos seus estudos humanísticos. Mas é a partir do século XVI que a Universidade colocará seu nome de vez na história ocidental:

Em consonância com as determinações do Concílio de Trento, Salamanca instituiu, em 1560, uma cadeira apologética. Teólogos da envergadura de Francisco de Vitória (1483-1546), Bañes (1528-1604), Domingos de Soto (1484-1560), todos dominicanos, e o jesuíta Francisco Suárez (1548-1617) ilustraram, sobremaneira, o studium Salmanticence, seja em filosofia, seja em teologia. Com esse corpo de professores, ofuscou-se o brilho da Sorbona. (ULLMANN, 2000, p. 295).

Nesse ambiente universitário fez-se necessário refletir sobre os novos tempos, o que consistiu em lidar com o desconhecido, o diferente, o novo, isto é, a descoberta da América e suas consequências. O descobrimento trouxe consigo diversas questões jurídicas, filosóficas, teológicas e morais. Sobre os problemas jurídicos, pode-se citar: "[...] el atinente a la forma más conveniente de tomar posesión de las tierras; el relativo al derecho al dominio político que España tenía sobre las tierras descubiertas; $y$, en fin, el referente a la licitud de la guerra que se hacía a los indios, que habían de repercutir necesariamente sobre el derecho a la conquista". (RUIZ, 2007, p. XXXVII-XXXVIII).

Antes mesmo da descoberta da América, em 1492, portugueses e espanhóis já haviam traçado planos para tomarem posse das eventuais terras encontradas. Nesse sentido, os monarcas se cercavam de juristas e eclesiásticos, a fim de concretizarem seus planejamentos ${ }^{1}$. Após o desco-

1 Sobre esse ponto, pode-se fazer menção aos seguintes documentos pontifícios: Sicut Carissimus (04/04/1418), Cum dum praeclarae (09/01/1433), Divino Amore (08/01/1452), além do Tratado de Alcáçovas (04/09/1479). Cf. RUIZ, 2007, p. XXXVIII-XXXIX, nota 5. 
brimento, em 3 de março de 1493, o papa Alexandre VI expede a bula Inter Cetera, primeira de cinco documentos, que ficarão conhecidas como bulas alexandrinas. Juntamente com outras nove bulas, estes documentos davam a posse aos espanhóis e também reis católicos, Fernando e Isabel, e à coroa portuguesa as terras que seriam descobertas:

\footnotetext{
Lo que debe resaltarse es que, al momento de otorgase, la doctrina y la práctica política consideraba que la potestad pontificia podía otorgar las tierras nuevas pobladas por paganos. Expedidas las bulas, se planteó inmediatamente la cuestión de si concedían un verdadero dominio político o sólo un poder especial para propagar el Evangelio; y, si se trataba de un dominio político auténtico, se suscitó el tema de cómo se incorporaban a la Corona de Castilla. (RUIZ, 2007, p. XLVI-XLVII).
}

Com a colonização, a terra descoberta foi dividida e os índios foram encomendados aos colonizadores. A encomienda consistia em um contrato no qual o rei cedia ao colonizador o direito de angariar riquezas, enviando uma parte para a metrópole, mas este ficava obrigado a educar os índios sob seus cuidados na fé cristã e a defender as novas terras em nome da Coroa.

Inicia-se na Europa um debate a respeito dos índios e das terras recém achadas. Tinham os indígenas direitos sobre a terra onde se encontravam? As terras eram da Coroa? Tais questões não estavam muito claras entre os pensadores europeus. No ponto de vista dos reis e colonizadores, as terras descobertas deviam ficar em posse dos europeus, uma vez que o interesse econômico estava presente. Por outro lado, dentre os intelectuais, as questões postas eram mais difíceis de serem respondidas.

\section{O CONTEXTO JURÍDICO DE FRANCISCO DE VITÓRIA}

Embora tenha estudado Artes e Teologia na Universidade de Paris, Francisco de Vitória acabou também influenciado pelo conteúdo jurídico que se disseminava na Europa, com o renascimento da jurisprudência romanista.

Seu ambiente de formação e, sobretudo de docência, já na maturidade, é permeado por uma consciência normativa e argumentativa, com análise de casos práticos.

Sob a luz dos comentadores ou bartolistas ${ }^{2}$, Francisco de Vitó-

2 Os comentadores constituíram um movimento de análise do Corpus Juris Civilis, durante os séculos 
ria interessou-se pela análise jurídica das autoridades civil e eclesiástica, examinando o exercício de seus poderes, bem como sua relação. Definiu a preeminência da autoridade espiritual do Papado sobre o poder civil, mas não a autoridade temporal, e foi um dos precursores a trabalhar os princípios dos direitos das gentes, embrião do Direito Internacional, na obra já citada De Potestate Civili.

É sintomático o fato de Vitória culminar sua carreira como catedrático na Universidade de Salamanca, grande centro de estudos romanistas, fundado sobretudo no mos italicus juris docendi.

O mos italicus foi o método de análise e ensino adotado pela Escola dos Comentadores ou pós-glosadores, a partir do século XIV, o qual imprimiu um sentido prático na utilização do Corpus Juris Civilis, com procedimentos filológicos, analíticos e sintéticos, integrando fontes locais do Direito na sua aplicação. O método ainda guardava reverência à autoridade do Corpus, mas também se utilizava das glosas da escola anterior (dos glosadores) e dos costumes regionais, dos princípios feudais e do direito eclesiástico. Adotou-se o método de "argumentação, debate e polêmica típico da escolástica" (CAENEGEM, 2000, p. 74), que permitiria ao Direito assumir uma postura científica.

Da análise do texto romano extraíam-se princípios gerais a guiarem a solução de casos concretos. Preservava-se, no entanto, a autoridade do texto, cujos princípios eram incontestáveis.

O objetivo era alcançar o sensus do texto, isto é, seu intento já não se satisfazia em aclarar a letra (littera) do Corpus, como os glosadores fizeram, mas atingir o seu espírito, o seu conteúdo prático.

Juntamente com outros teólogos morais e juristas espanhóis, Vitória promove o jusracionalismo europeu, naquele momento atrelado ao renascimento da jurisprudência romana.

Esse renascimento da jurisprudência encontrou nas universidades laicas recém-constituídas o ambiente propício para recusar as tradições feudais e aliar-se aos interesses burgueses. As mudanças jurídicas principais deveram-se, sobretudo, à unidade do objeto das ciências jurídicas, que se debruçaram sobre o Corpus Juris Civilis, e à unidade de métodos

XIV a XVI, que atuou no renascimento da jurisprudência romanística. Naquela época, nas recentes universidades de Direito, o Corpus foi utilizado como uma fonte de racionalização dos métodos jurídicos, permitindo o ressurgimento da técnica jurídica e da teorização e a valorização das abstrações normativas. Um dos mais importantes membros desse movimento foi Bártolo de Sassoferrato, jurisconsulto italiano reconhecido por seus comentários. Em razão de sua fama, os juristas dessa escola eram também conhecidos por bartolistas. Esse reconhecimento deu origem a um adágio latino muito famoso nas universidades de Direito da Idade Moderna: Nemo bonus jurista nisi bartolista, isto é, "ninguém é bom jurista se não for bartolista". 
empregados pelos juristas, dentre os quais a dialética escolástica.

Sob as luzes que formariam a moderna Escola de Direito Natural, Francisco de Vitória é um dos precursores da nova ciência jusnaturalista, no esteio da tradição tomista, mas com um objetivismo axiológico, pelo qual os valores e princípios assumem validade objetiva e universal, independentemente da experiência dos indivíduos.

Hugo Grotius (1583-1645), grande expoente da Escola de Direito Natural e considerado por muitos como o pai do Direito Internacional, em De Jure Belli ac Pacis (1625), refere-se a Francisco de Vitória como uma de suas influências tanto na elaboração dos princípios que advêm da experiência jurídica comum oferecida pela tradição moral-teológica espanhola, sobretudo sobre o direito das guerras coloniais e religiosas, como na restrição à posição do papa Inocêncio IV (GROTIUS, 2005).

O papa Inocêncio IV sustentou a justeza da guerra contra aqueles que contrariassem a natureza e Francisco de Vitória, por outro lado, a admitia apenas quando ofendesse o Estado ou quando alguém que estivesse sob a jurisdição do Estado fosse prejudicado. Exigia-se, pois, a injúria e não o simples fato de ser infiel. (GROTIUS, 2005, Livro II, Cap. XX).

Vitória representa o elo entre a tradição canônico-argumentativa medieval e o racionalismo jurídico.

\section{FRANCISCO DE VITÓRIA E A QUESTÃO INDÍGENA}

Em 1510, o teólogo escocês John Mair (1467-1550) discute, em sua obra Comentário ao Livro II das Sentenças, a legitimidade da conquista das terras descobertas. Seu argumento era a favor da posse. Ele empregava uma teoria utilizada no contexto europeu, que consistia na justificação jurídica das guerras contra os infiéis (tártaros e muçulmanos) que invadiam terras cristãs injustamente, além do argumento de que os infiéis eram hostis aos cristãos. A tese utilizada fazia um paralelo entre os infiéis europeus e os "infiéis" americanos, justificando, assim, a guerra contra eles. Mas, e se os índios forem pacíficos? Ainda assim, o teólogo utiliza dois argumentos para defender a posse das terras novas:

El primero es el de la vía misional, basada en la teoría atenuada de Inocencio IV sobre el poder universal indirecto del Papa sobre los paganos para compelirlos a abrazar la fe y obligar a bautizar a sus niños. Esta prevalencia del Derecho divino de la fe presto se convierte en poder directo de ocupación preventiva, protección por 
las armas de la predicación y facultad de imponer tributos; por fin, a los príncipes infieles que resisten a la fe puede la Iglesia privarles de su jurisdicción y deponerles en beneficio de los príncipes cristianos. En el segundo argumento, Mayor admite el estado de barbarie de los indios que les hace esclavos por naturaleza según la teoría aristotélica. Por ello es lícito al príncipe cristiano sojuzgarles, ocupar sus tierras y someterles a efectiva servidumbre. (URDANOZ, 1974, p. 118).

Pode-se perceber que o primeiro argumento está pautado na submissão do poder civil ao poder eclesiástico. O segundo, baseado em Aristóteles, parte do pressuposto de que os índios seriam bárbaros, por isso, são escravos por natureza. Tais teses foram usadas insistentemente pelos defensores da submissão indígena e da tomada das terras americanas. Para Aristóteles (1998), conforme posto na obra A Política, existiam dois tipos de escravos: os escravos por natureza, que não tinham capacidade intelectual para comandarem a si próprios e possuírem propriedades, o que Mair interpreta ser o caso dos índios, e os escravos por convenção, que seriam os homens capturados na guerra.

Por sua vez, em 1511, uma voz dissonante à do teólogo escocês se fez levantar. Era o dominicano Antônio de Montesinos (1475-1545) que, em um sermão do tempo do advento, interpela os espanhóis com os seguintes dizeres:

Com que direito haveis desencadeado uma guerra atroz contra essas gentes que viviam pacificamente em seu próprio país? Por que os deixais em semelhante estado de extenuação? Por que os matais a exigir que vos tragam diariamente seu ouro? Acaso não são eles homens? Acaso não possuem razão e alma? Não é vossa obrigação amá-los como a vós próprios? (ANTÔNIO DE MONTESINOS apud SALES, 2012, p. 52).

Contrariamente a Mair, que tomava os Índios como seres sem razão, o argumento utilizado por Montesinos é de que eles são homens, pois possuem racionalidade e alma, e, por isso, não podiam ser dominados.

A partir dessas diferentes posições, a Europa entrará em uma disputa para justificar a destruição e a posse das novas regiões ou o cuidado e a fraternidade com os habitantes da América. Interessante notar que, através de atores diferentes, a mesma Europa que destruirá a cultura americana será também aquela que defenderá o direito dos povos indígenas.

Inserido neste debate está o nome de Francisco de Vitória (1483- 
1546). Vitória nasceu em Burgos, na Espanha, em 1483. Entrou para o Convento dominicano de São Paulo em sua cidade. Possivelmente, em 1508, foi enviado ao Convento de Santiago, em Paris, pelos seus superiores, a fim de que estudasse Humanidades, Artes e, posteriormente, Teologia, tendo aula com o já citado John Mair. Em 1522, adquiriu o título de Doutor em Teologia. Em 1523, foi para a cidade de Valladolid, atuando no Colégio de São Gregório, onde teve a oportunidade de explicar em aula a Suma Teológica de Tomás de Aquino, grande inspirador da segunda Escolástica.

Em 1526, após o falecimento de Pedro de León, os dominicanos convidam Vitória para assumir a Cátedra Primeira, que conservou até 1546, ano de sua morte:

En Salamanca consiguió gran prestigio por la profundidad y nítida exposición de las cuestiones de la Suma en sus relecciones o exposiciones solemnes y públicas. Así se convirtió en el maestro por excelencia de las relecciones. De entre ellas sobresalen las que se refieren al derecho, tanto civil interno y eclesiástico como internacional. (FRAYLE DELGADO, 2007, p. XI).

Francisco de Vitória adentra na temática das consequências do descobrimento com a preocupação de compreender se os índios estavam submetidos ao poder espanhol. No fundo, a questão consistia em analisar se os povos da América tinham propriedade (dominium) sobre seus bens e sobre as terras em que viviam. Assim, poder-se-ia decidir sobre a legitimidade ou não das conquistas espanholas.

É importante se voltar para as obras de Vitória, procurando fazer uma síntese dos seus argumentos, que compreenderão aspectos teológicos, filosóficos e jurídicos.

Na obra De Potestate Civili (1528), Vitória se pergunta sobre o poder secular. Para ele, a cidade não é uma criação artificial humana, mas:

[...] algo que brota de la naturaleza que sugirió este modo de vida de los mortales para su defesa y conservación [...] ninguna sociedad puede tener consistencia sin una fuerza o poder que la gobierne y la proteja. En efecto, la utilidad y finalidad del poder público y de la sociedad o comunidad son una misma cosa". (FRANCISCO DE VITÓRIA, 2007, p. 13). 
A cidade é uma criação natural que necessita de um poder para se preservar; entretanto, tal capacidade e poder emanam de Deus.

Francisco irá se indagar se os que governam as repúblicas dos infiéis (pagãos) possuem príncipes e magistrados legítimos. Valendo-se de Paulo e Pedro como autoridades, o pensador espanhol afirma que:

\begin{abstract}
Además no hay que poner en duda que entre los paganos haya príncipes y señores legítimos, puesto que el Apóstol en los textos antes citados manda obedecer a los poderes y a los príncipes y servirles en todo tempo; y éstos ciertamente entonces eran todos infieles. José y Daniel eran administradores y ministros de los príncipes paganos. Y los príncipes cristianos seculares o eclesiásticos no podrían privar a los infieles de tal potestad y principado sólo por el hecho de ser infieles, a no ser que hubieran recibido de ellos otra cualquier injuria. (FRANCISCO DE VITÓRIA, 2007, p. 22) $(\mathrm{I}, 9)^{3}$
\end{abstract}

Para Francisco de Vitória, mesmo os governos dos povos indígenas eram legítimos, pois os apóstolos mandavam obedecer a qualquer governo existente, por estarem submetidos ao poder de Deus. Por outro lado, afirma que os príncipes cristãos ou eclesiásticos não possuem o direito de negar o poder dos povos infiéis, mesmo que eles não compactuem com a mesma fé.

Se na obra De Potestate Civili Vitória se debruça sobre o poder civil de uma maneira geral, nas obras De Indis Recenter Inventis, relectio prior (Sobre os índios recentemente descobertos, relectio primeira (15381539)) e De Indis, sive de jure belli hispaniorum in bárbaros, relectio posterior (Sobre os índios ou Sobre o direito da guerra dos espanhóis sobre os bárbaros, relectio segunda (1539)), o pensador irá se deter sobre as questões que envolvem a descoberta e os índios. Estas três obras são do seu período em Salamanca. Fazem parte dos escritos denominados relectiones. Havia uma obrigação nas universidades de o professor proferir uma lição

3 Os textos referidos de Paulo utilizados como autoridade estão em Epístola aos Romanos: Rm 13, 1-2: "Submetam-se todos às autoridades constituídas, pois não há autoridade que não venha de Deus, e as que existem foram instituídas por Deus. Quem se opõe à autoridade, se opõe à ordem estabelecida por Deus. Aqueles que se opõem, atraem sobre si a condenação". Epístola a Tito: Tt 3, 1: "Lembre a eles que devem ser submissos aos magistrados e autoridades, que devem obedecer e estar prontos para toda

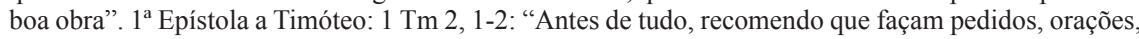
súplicas e ações de graças em favor de todos os homens, pelos reis e por todos os que têm autoridade, a fim de que levemos uma vida calma e serena, com toda a piedade e dignidade". O texto de Pedro está em $1^{a}$ Epístola de Pedro: 1 Pe 2, 13-14: "Submetam-se a toda criatura humana por causa do Senhor, seja ao rei como soberano, 14 seja aos governadores como enviados dele para punir os malfeitores e para louvar os que fazem o bem". Cf. BÍBLIA SAGRADA: Edição Pastoral. Disponível em: <http://www. paulus.com.br/biblia-pastoral/_INDEX.HTM>. Acesso em: 30 abr. 2017. 
pública sobre seus estudos uma vez por ano; tais textos ficaram conhecidos como relectiones: "Dichas relecciones eran exposiciones solemnes que los catedráticos hacían cada año para toda la comunidad universitaria y, según la tradición y costumbre, tenían lugar en días festivos para facilitar la asistencia de todos". (FRAYLE DELGADO, 2007, p. XII).

Na primeira relectio sobre os índios, Vitória afirma que tal escrito se deve "por causa de esos bárbaros del Nuevo Mundo, llamados vulgarmente indios que desconocidos antes en nuestro mundo han venido hace cuarenta años a poder de los españoles". (FRANCISCO DE VITÓRIA, 2007, p. 59). O tema central é o índio americano.

Inicialmente, Vitória está interessado em saber se os índios, antes da chegada dos espanhóis, eram os donos de suas posses e se existiam verdadeiros príncipes entre eles. $\mathrm{O}$ argumento dos que defendiam a posição de que os índios não tinham e não poderiam ter posses estava baseado no fato de: a) serem pecadores e infiéis; e b) serem idiotas e dementes (i.e., não possuírem razão). Em relação ao primeiro argumento, contrariamente, Francisco de Vitória (2007, p. 70) afirma que "El pecado mortal no impide el dominio civil ni el verdadero dominio". Para defender tal afirmação, Vitória utiliza sete argumentos: 1- o pecador não perde o domínio natural (dom de Deus) e o domínio civil (dom de Deus e direito humano), pois, permanece com o domínio dos próprios atos e membros, o que prova o direito de defender a própria vida; 2- as Sagradas Escrituras chamam homens maus e pecadores de reis (Salomão, Acabe e outros), que, por conseguinte, são também donos; 3- o domínio se funda na racionalidade (imagem de Deus), sendo que o pecado não retira a racionalidade; 4- o rei Davi também era um pecador; 5- o Gênesis $(49,40)$ fala da possibilidade de um reino ser governado por um rei mau; 6- assim como o pecado mortal não retira $o$ poder espiritual (p.ex. um mau bispo tem poder para ordenar sacerdotes), $o$ pecado também não retira o poder civil; 7- as Escrituras (Rm 13, 5 e 1Pe 2, 18) falam em obediência aos príncipes (mesmo maus) e o preceito de não tomar a coisa alheia. (FRANCISCO DE VITÓRIA, 2007, p. 71-72).

Em seguida, Vitória irá se debruçar sobre esta questão: se a infidelidade é motivo para a perda do domínio. Para ele, "La infidelidad no es impedimento para ser verdadero dueño". (FRANCISCO DE VITÓRIA, 2007, p. 73). Sua reflexão se pautará na Suma Teológica (IIaIIae, q. 90, a. 10 e a. 12) de Santo Tomás de Aquino e em algumas passagens das Escrituras (Rm 13, 5; 1Pe 2, 18; To 2, 13 e Gn 47, 20-21), que ilustram reis infiéis no poder e a necessidade de obedecer a tais monarcas. Em suma, 
a infidelidade não é capaz de destruir o domínio seja no direito natural, seja no direito positivo, incluindo neste último a posse de bens materiais. Obviamente, pensando nos indios, Francisco de Vitória (2007, p. 74) afirma que "De lo cual se deduce claramente que no es lícito despojar a los sarracenos, a los judíos y a cualesquiera de los infieles de los bienes que poseen, sólo por el hecho de ser infieles. El hacerlo es hurto o rapiña como si se hiciera a los cristianos".

Francisco de Vitória (2007, p. 78) concluí sobre a questão analisada, "Que ni el pecado por infidelidad ni otros pecados mortales son obstáculo para que los bárbaros sean verdaderos dueños tanto pública como privadamente, y que por este título los cristianos no puedan ocupar sus bienes e sus tierras". Assim, fica permitido aos bárbaros infiéis, na visão do dominicano, possuírem propriedade, o que significa que mesmo os cristãos não podem retirar e invadir as propriedades dos índios.

Vitória, então, se debruça sobre o segundo ponto: se os que não possuem razão (idiotas) não podem ter propriedade, ou, em outras palavras, "si para que uno sea capaz de dominio se riquiere el uso de razón". (FRANCISCO DE VITÓRIA, 2007, p. 78). Nesse contexto, será discutido se os índios possuem ou não razão.

Primeiramente, Vitória analisa a noção de Conrado Summerhart (1455-1502) de que, para haver domínio, não é necessária a razão. Para este teólogo, o domínio se estende às criaturas irracionais, já que, em sua visão, domínio é o direito de usar algo em seu proveito. Por exemplo, os brutos têm direito sobre as ervas e as plantas (Gn 1,29-30) e os astros têm o direito de iluminar (Gn 1, 17-18). Entretanto, Vitória não compartilha dessa visão, pois, para ele, as criaturas irracionais não possuem domínio pelo fato de não terem direito, aliás, como afirma o próprio Conrado. Não possuem direito, pois não podem sofrer injúria. (FRANCISCO DE VITÓRIA, 2007, p. 78-79).

Baseando-se em Tomás de Aquino, Vitória afirma que apenas a criatura racional possui domínio sobre os seus atos, isto é, capacidade de decidir sobre isso ou aquilo, já que, por um lado, "si los brutos no tiene dominio sobre sus actos, tampoco sobre las demás cosas" (FRANCISCO DE VITÓRIA, 2007, p. 80). Por outro lado, os animais também não movem a si mesmos, mas são movidos, não tendo, pois, domínio (FRANCISCO DE VITÓRIA, 2007, p.80). O ponto fundamental nesses argumentos é o fato de que para algo ter domínio é preciso que seja senhor dos próprios atos.

Em seguida, Vitória se pergunta se uma criança, antes do uso 
total da razão, tem domínio. A resposta é “[e]sto é evidente porque pueden sufrir injurias, luego también tienen derecho sobre las cosas; luego también dominio, que no es sino derecho". (FRANCISCO DE VITÓRIA, 2007, p. 81). A questão permite ao autor afirmar a tese teológica de que o fundamento do domínio é a imagem de Deus, igualmente presente nas crianças.

No caso dos dementes, os que não fazem uso da razão e nunca farão, estes também podem ter posse, na medida em que podem sofrer injúrias, o que significa possuírem direitos. ${ }^{4}$ (FRANCISCO DE VITÓRIA, 2007, p. 82). Os bárbaros (índios) também não são dementes, uma vez que:

Se prueba porque en realidad no son dementes sino que a su manera tienen uso de razón. Está claro, porque tienen cierto orden en sus cosas, una vez que poseen ciudades establecidas ordenadamente, y tienen matrimonios claramente constituidos, magistrados, señores, leyes, artesanos, mercaderes, cosas todas ellas que requieren el uso de razón; asimismo tienen una especie de religión, no yerran en cosas que son evidentes para los demás, lo cual es indicio de uso de razón. (FRANCISCO DE VITÓRIA, 2007, p. 82).

A citação acima é espetacular, no sentido de ilustrar um autor do século XVI descrevendo tão bem o modo de vida indígena, além de escancarar a tese de que os índios são tão homens quanto os europeus, pois possuem razão (apesar de poderem aperfeiçoá-la, na visão de Vitória) e, por isso, têm capacidade de domínio, o que significa que as terras americanas eram deles, e que os espanhóis (e portugueses) não respeitaram

4 Roberto Pich chama a atenção para as possíveis interpretações sobre este ponto: "A dificuldade interpretativa é a seguinte, e é respectiva às proposições de Vitoria sobre os amentes: acredita ele que uma medida mínima de participação na razão - que possibilita apenas obedecer a um senhor por natureza - já basta para domínio de algo ou, de fato, ele não aceita que a deficiência permanente de razão fosse tese convincente sobre seres humanos quaisquer, uma vez que pareceria ferir alguma outra convicção filosófica ou teológica? Quase desnecessário dizer que nesses casos Vitoria basicamente acredita que os índios são "bárbaros", no sentido específico de que desenvolveram pouco as suas potências racionais ou não têm um estágio de cultura e civilização à altura daquele dos espanhóis. Não cabe aqui relativizar ou repudiar esse juízo, mas convém dizer que, em Vitoria, ele seria só um juízo de apreciação cultural, não antropológico. Nada nos textos de Vitoria dá a entender que ele aceitaria a primeira hipótese - a qual, de fato, é eventualmente insustentável -; e, embora não afirme literalmente a segunda hipótese, tudo leva a crer que a toma como mais provavelmente verdadeira (lembrando que a relectio tem como meta argumentar em favor de sentenças mais prováveis segundo a razão). A última sentença sobre a atribuição de deficiência em razão dos bárbaros e a consequente impugnação de seu domínio é essa: "E seja o que for sobre isto [= ou seja, o parecer dos jurisconsultos sobre o domínio civil], eis a quarta proposição: tampouco desta parte [= da parte do pleno domínio civil] os bárbaros estão impedidos de serem verdadeiros donos". Como já dito, essa última sentença sobre o tema acrescenta algo sobre a anterior: mesmo se o atributo da "deficiência em razão" for atestado aos bárbaros, conclui-se que eles têm domínio, e isso tanto natural quanto civil. No que segue, sugiro que a segunda hipótese descrita acima esteja à mão" (PICH, 2012, p. 389-390). 
tal condição. Além do mais, o autor acredita que os índios possuem uma religião, sendo capazes de agir corretamente através da razão como toda a humanidade. A conclusão é de que há uma única natureza humana. Talvez aqui esteja o nascedouro dos direitos humanos modernos.

Para Vitória, não resta dúvida de que os índios eram senhores antes da chegada dos espanhóis, por isso, donos do que possuíam. Assim,

[...] los bárbaros eran pública y privadamente tan dueños como los cristianos, y que tampoco por este título ni sus príncipes ni los particulares pudieron ser despojados de sus posesiones como no fueran verdaderos dueños. Y sería inicuo negarles a éstos, que nunca nos hicieron ninguna injuria. (FRANCISCO DE VITÓRIA, 2007, p. 82$83)$.

A partir do argumento principal analisado acima, Vitória irá ponderar sobre outros temas relacionados à conquista. Em seu texto, há uma crítica ao poder dos governantes civis, como também uma crítica ao poder papal. No início da segunda parte do De Indis Prior, o pensador espanhol se pergunta se o imperador tinha direito de dominar toda a terra. Claramente, a questão de fundo é se os governantes espanhóis, enquanto reis, tinham direito sobre as novas terras. Para Francisco de Vitória (2007, p. 91), a resposta será negativa, pois, "el dominio no puede ser sino de derecho natural, bien sea divino, bien humano. Ahora bien, por ninguno de esos derechos hay un solo señor de todo el orbe".

Outro argumento utilizado por aqueles que defendiam a posse das novas terras pelos monarcas europeus era baseado no fato de que alguns compreendiam o papa como sendo o monarca de toda a orbe, e ele, por sua vez, reconhecia o direito do imperador sobre as terras descobertas. Francisco de Vitória (2007, p. 99), pautado na autoridade de Cristo, afirma "Y si Cristo no tuvo el dominio temporal, como antes hemos defendido como lo más probable, y también de acuerdo con la sentencia de Santo Tomás, mucho menos lo tendrá el Papa, que es su vicario". Além do mais, "El Papa, sin embargo, no tiene tal potestad sobre los infieles, ni podría excomulgarlos, ni prohibirles los casamientos permitidos por el derecho divino". (FRANCISCO DE VITÓRIA, 2007, p. 100).

Mesmo que os bárbaros não queiram aceitar Cristo, não se pode fazer guerra contra eles ou causar qualquer dano, pois, se assim fosse, tal atitude seria corriqueira em terras cristãs, já que existem infiéis que permanecem com suas posses: "De lo dicho se desprende claramente que los 
españoles, cuando por primera vez llevaban navegando a las tierras de los bárbaros, no llevaban consigo ningún derecho para ocupar sus territórios". (FRANCISCO DE VITÓRIA, 2007, p. 105).

No início da terceira parte do De Indis Prior, Vitória defende a tese de que os espanhóis poderiam permanecer nos novos territórios, desde que não fizessem mal algum aos nativos, e estes não poderiam proibir os espanhóis de permanecerem ali. Apressadamente, poder-se-ia alegar que tal visão é a visão do colonizador; no entanto, a posição de Vitória, mais uma vez, é surpreendente. A justificativa se basearia em um direito comum existente para todos os povos da Terra! Vitória elenca quatorze motivos para as relações entre os povos. O primeiro, por ser de grande lucidez, merece ser transcrito:

Se prueba, primero, por el derecho de gentes, que es derecho natural o se deriva del derecho natural, según el texto de las Instituciones 'Lo que la razón natural ha establecido entre todas las gentes se llama derecho de gentes'. En efecto, en todas las naciones se tiene por inhumano el tratar mal, sin motivo alguno especial, a los huéspedes y transeúntes y, por el contrario, es de humanidad y cortesía portarse bien con los transeúntes que viajan a otras naciones. (FRANCISCO DE VITÓRIA, 2007, p. 130).

O que há por trás dessas palavras é a percepção de que, devido a um direito comum, os homens devem tratar bem uns aos outros, o que demonstra humanidade. A intercomunicação entre os homens também é um motivo que justifica uma relação respeitosa entre os povos, já que há uma comunhão entre as nações, permitindo, assim, que os homens possam passar por todas as regiões do planeta. Em suma, há um direito de ir e vir entre os povos:

Segundo. Al principio del mundo, siendo todas las cosas comunes, a cualquiera le estaba permitido dirigirse y recorrer las regiones que quisiera. Y eso no parece que haya sido abolido por la división de bienes, pues nunca fue intención de las gentes suprimir la intercomunicación de los hombres por ese reparto, y en Verdad en tiempos de Noé eso hubiese sido inhumano. (FRANCISCO DE VITÓRIA, 2007, p. 130).

De acordo com um direito comum, espanhóis e bárbaros podem fazer comércio entre si, desde que não haja prejuízo aos cidadãos de ambas comunidades. Assim, o comércio está autorizado, se há excesso dos produ- 
tos comercializados. (FRANCISCO DE VITÓRIA, 2007, p. 132).

Na segunda relectio sobre os índios - De Indis, sive de jure belli hispaniorum in bárbaros, relectio posterior -, Vitória retoma a primeira relectio, mas se preocupa em justificar a guerra e a ocupação da terra descoberta.

Dissertando sobre o que seria uma guerra justa, Vitória faz afirmações importantes a respeito das relações entre os povos. O pensador trabalha três motivos insuficientes para se declarar uma guerra justa: a) diversidade religiosa; b) a pretensão de se estender os domínios; e c) a glória do príncipe ou outro proveito particular. (FRANCISCO DE VITÓRIA, 2007, p. 173-174).

Pode-se notar que tais motivos eram alegados pelos conquistadores a fim de dizimarem os povos americanos. Por isso, a própria ideia de colônia exploradora é um equívoco, pois pressupõe os itens (b) e (c).

É possível identificar em Vitória alguns elementos comuns aos direitos humanos contemporâneos. Direitos esses que seriam inerentes à natureza humana. Ao falar dos índios americanos, Vitória, na verdade, fala do homem em geral. É possível perceber a inalienabilidade, a inviolabilidade, a igualdade e a universalidade de um direito comum a todos os homens em Vitória. Portanto, tal direito nunca é perdido, deve ser sempre respeitado, é idêntico e comum para todos:

La inalienabilidad porque para Vitoria, son derechos unidos al mismo ser racional del hombre, por lo que no se pierden en ninguna ocasión, ni aun en el caso en que no se puedan ejercitar por las limitaciones que pudiera imponer el derecho positivo.

La inviolabilidad porque a lo largo de sus reelecciones invoca el respecto sobre estos derechos; respecto que afirma en defensa de los indios y se basa en la dignidad e integridad de la persona, el honor debido al hombre, el respeto a sus posesiones y formas de administración política.

La igualdad viene a ser también una cualidad necesaria de los derechos humanos, derivada de la misma formulación, al establecer como campo de derechos el universo de todo el género humano, es decir, propugna que todos los seres humanos deben disfrutarlos por igual.

Y la universalidad porque los derechos humanos se enuncian y reconocen para todo ser racional. El carácter humano es lo que determina la base de todos estos derechos, porque son propios a su misma naturaleza. (MORA HERNÁNDEZ, 2013, p. 44). 
Não havia um ideal em Vitória para caracterizar os direitos humanos fundamentais; entretanto, a análise do caso concreto do "descobrimento" foi crucial para chegar a tais características.

\section{SOBRE ALTERIDADE: A ÉTICA PERANTE O DIFERENTE}

A alteridade assumiu um papel tão fundamental na Ética moderna que é possível verificar sua presença e desenvolvimento em pensadores com premissas bastante díspares, como Francisco de Vitória e Jean-Paul Sartre, mas que, nessa temática, mostram também complementaridade de reflexões.

O posicionamento teológico de Vitória e o existencialismo ateu de Sartre guardam o ponto comum da defesa do humano e do reconhecimento do outro. Sartre fez coro com aquele na luta contra o determinismo político: Vitória encontrava-se no contexto da colonização no Novo Mundo, sob o argumento de "humanizar" os infiéis; Sartre, na liberdade ínsita do eu.

A liberdade sartreana estava na aptidão do ser humano para ser criador de sentido, para interrogar. A liberdade não é uma qualidade ou característica do humano, mas é o próprio humano. Por isso, ele afirma:

Com efeito, se admitíssemos que a interrogação é determinada pelo determinismo universal, deixaria de ser não apenas inteligível, mas até concebível. [...] por duplo movimento de nadificação, o interrogador nadifica com relação a si o interrogado, colocando-o em estado neutro, entre ser e não-ser, e ele próprio nadifica-se com relação ao interrogado, descolando-se do ser para poder extrair de si a possibilidade de um não-ser. [...] A interrogação é, portanto, por definição, um processo humano. Logo, o homem apresenta-se, ao menos neste caso, como um ser que faz surgir o Nada no mundo, na medida em que, com esse fim, afeta-se a si mesmo de não ser. (SARTRE, 2007, p. 66).

O interessante é que esse "processo de constituir-se" do sujeito não se faz solitariamente, embora individualmente. Na obra de Vitória, identifica-se um discurso de afirmação do índio, contingencial e necessário para que o europeu se perceba e perceba ao outro. E o mais importante, que não releve a sua conduta ao plano da irrelevância ou da irresponsabilidade. Sartre reconhece o ser humano como único definidor de mundo e de si mesmo, mas também como detentor de responsabilidade absoluta por 
aquilo que conscientemente reconhece. Como destaca José Luis Pérez:

Em Sartre, a responsabilidade decorrente da liberdade individual denota, portanto, a necessidade contínua, para cada indivíduo humano, de responder aos pares que o observam por ocasião de cada acção (sic), na expectativa de uma definição do que é essa realidade humana que fica sempre por ser dita. [...] A responsabilidade constituise, por conseguinte, como o exacto (sic) ponto em que a odisseia da liberdade individual, que é essa existência própria e singular de um só humano, se reconhece como uma aventura verdadeiramente comunitária. (PÉREZ, 2012, p. 311).

Assim, a liberdade que existe individualmente contextualiza-se intersubjetivamente no outro. Pode-se perceber que a liberdade pressupõe um momento individual - de compreensão, deliberação e ação - e um momento relacional, na avaliação de si mesmo e do mundo, a partir de suas experiências prévias, seus valores e seus modelos de compreensão.

Para além do poder de ação do indivíduo, a liberdade projeta-se na ordenação conceitual do mundo - pelo qual, na interrogação, "nadificase", como diria Sartre.

Por essa razão, a liberdade faz gerar, em codependência, a responsabilidade. Nas palavras do próprio Sartre:

Quando declaro que a liberdade, através de cada circunstância concreta, só pode ter como alvo querer-se a si mesma, então, se o homem reconhecer que, em seu desamparo, é ele que estabelece valores, ele não poderá mais querer senão uma coisa, a liberdade como fundamento de todos os valores. Isto não significa que ele a queira abstratamente. Isto quer dizer simplesmente que os atos dos homens de boa fé têm como última significação a busca da liberdade enquanto tal. Um homem que adere a tal sindicato, comunista ou revolucionário, quer objetivos concretos. Estes objetivos implicam uma vontade abstrata de liberdade, mas esta liberdade se quer concretamente. Queremos a liberdade pela liberdade e através de cada circunstância particular. E, querendo a liberdade, descobrimos que ela depende inteiramente da liberdade dos outros, e que a liberdade dos outros depende da nossa. Claro, a liberdade como definição do homem não depende de outrem, mas, uma vez que existe engajamento, sou obrigado a querer minha liberdade ao mesmo tempo que a liberdade dos outros; eu só posso tomar minha liberdade como alvo se, do mesmo modo, eu tomar a liberdade dos outros como alvo. (SARTRE, 2009, p. 636).

Há, pois, um elemento oculto e fundamental nas defesas de Vi- 
tória e de Sartre, o alter, que, mesmo na liberdade individual, impõe o reconhecimento do outro. Esse elemento impõe a assunção de uma posição ética de respeito ao outro; por isso, não é pautada no racionalismo dominador, que reduz o outro a mais um objeto, mas na identificação do outro como sujeito livre para constituir a sua própria dignidade.

A Ciência do Direito, por vezes, reconhece a alteridade apenas do ponto de vista formal, isto é, como a necessária relação com outro indivíduo, expressa na fórmula: Ubi jus ibi societas. No entanto, a alteridade no Direito deve se pautar no reconhecimento das individualidades, nas diferenças do indivíduo concreto, seja ele cristão ou "bárbaro", europeu ou americano. Nesse sentido, também ocorre o alerta de Roberto de Aguiar, ao afirmar que há uma:

[...] fixidez dogmática de raiz metafísica do senso comum jurídico [que] não trata do jurídico a partir da relação entre diferentes, mas a partir de uma norma uniformizadora, que dilui os sujeitos no interior de uma igualdade abstrata e retira dos envolvidos na relação jurídica os seus rostos, suas existências e concretude. (AGUIAR, 2006, p.

Assim, a alteridade ultrapassa o reconhecimento do outro como sujeito, para alcançá-lo como ser único, livre e responsável, ao qual se deve respeitar em sua diferença e autonomia. É essa a defesa que Vitória faz dos índios: reconhece-os como seres racionais e, por isso, senhores de seus atos; e como detentores de direitos sobre a terra, pois capazes de domínio.

\section{DA ALTERIDADE AOS DIREITOS HUMANOS}

Do reconhecimento da alteridade dos índios, Francisco de Vitória faz decorrer a solidariedade comum e a responsabilidade recíproca nas relações entre povos.

Vitória faz nascer a universalização dos direitos e, na base jusnaturalista, permite que, mais tarde, as características por ele atribuídas aos direitos evoluam para a consideração dos direitos humanos. Estes, embora ainda não nomeados e conceituados pelo autor espanhol, já são entendidos como comandos que independem da ação dos Estados e que se justificam como deveres morais a serem universalizados. Refletem, pois, a aceitação - hoje tão frequente, mas na época de Vitória ainda restrita aos círculos 
eruditos - de que todos os seres humanos devem ter direitos, pois só há uma única natureza humana, caracterizada pela racionalidade.

Há autores contemporâneos que criticam a universalidade dos direitos humanos pautados no relativismo axiológico e cultural, isto é, não haveria direitos humanos universais, pois o pluralismo de valores e culturas exige um particularismo no reconhecimento dos direitos. Sobre essas objeções, Pérez Luño (1998) diz que muitas violações são perpetradas sob esse argumento, como é o caso do analfabetismo feminino e da mutilação genital feminina. E ainda rebate que esse relativismo não pode representar um "direito à indiferença", legitimador da impunidade. Sustenta, pois, que há caracteres racionais na tradição dos direitos humanos, que não podem ser desconsiderados. Há a necessidade de se compartilhar uma atitude ética no projeto de construção da modernidade.

A ideia de direitos a todos os homens corresponde à caracterização mais contemporânea dos direitos humanos. Pérez Luño (1999, p. 48), por exemplo, coloca-os como um conjunto de faculdades que "concretizam as exigências de dignidade, liberdade e igualdade humanas", algo semelhante à caracterização dos direitos dos indígenas frente aos europeus, por Vitória.

Francisco de Vitória (2007) cria um espaço global de não violência, um direito comum existente para todos os povos, o que exige comportamentos harmoniosos para uma comunhão entre as nações. Em síntese, há um direito de ir e vir entre os povos e não é aceitável a justificativa de guerra contra os bárbaros, simplesmente por serem infiéis ou pecadores. Pela mesma razão, não se autoriza a ocupação de suas terras ou a tomada de seus bens; ainda que bárbaros, eles têm direito ao domínio.

$\mathrm{O}$ fundamento da defesa do direito natural à igualdade se fez pela essência racional de todos os homens e o direito à liberdade está na própria criação do homem, que não foi criado para ser escravo nem para ser coagido. Não se justifica, pois, a coação que visa imbuir a fé no ser humano.

$\mathrm{Na}$ mesma linha, o teólogo aceita a justeza de algumas guerras, mas estas não podem se fundar apenas na diversidade religiosa ou na pretensão de se estender os domínios do príncipe, do Estado ou mesmo do Papado. Não há uma autoridade temporal sobre todo o mundo, nem do papa, nem dos reis espanhóis. (FRANCISCO DE VITÓRIA, 2007)

A guerra é justificável desde que seja um caminho utilizado após esgotadas as tentativas de paz; que se faça sem ódio, buscando unicamente a justiça; e que as consequências do triunfo não sejam desregradas e que 
se justifiquem na própria causa da guerra. (FRANCISCO DE VITÓRIA, 2007)

O homem é também reconhecido como ser social, dotado de direito à cidadania, e o poder político deve ser exercido em nome do povo. Por essa razão, também se reconhece em Vitória (2007) o direito à desobediência frente aos governantes que exercem o poder político em interesse próprio e não do povo.

Por fim, o embrião do livre comércio está nas ideias de Francisco de Vitória (2007), que defende a permissão para o comércio, ainda que com povos bárbaros, se houver excedente de produção.

\section{CONCLUSÃO}

Quando Francisco de Vitória precisa refletir sobre o outro, ele não se preocupa tanto com as diferenças, mas com aquilo que torna todos os homens seres humanos. Ao deparar com outras sociedades e culturas e com os índios, seu argumento parte do pressuposto de que o "outro" também é humano.

Assim como os europeus, os índios tinham direito de ter e conservar sua sociedade e seu estado. Vitória oferece argumentos que criticam a noção do colonizador. O que os espanhóis estavam fazendo era, do ponto de vista filosófico, teológico e jurídico de Vitória, um equívoco. Mesmo sem acreditar na mesma divindade, os índios tinham os mesmos direitos de domínio que os espanhóis.

Quando questionado sobre a racionalidade dos índios, Francisco tem a oportunidade de dizer que não só possuem razão, como esta é a mesma para todos. É esta razão que possibilitará aos índios terem sociedade, rituais, cidades e política. Nesse sentido, caso não houvesse um consenso entre os diferentes povos, a relação unilateral seria encarada como rapina.

Francisco sugere o outro como o mesmo, pois, em sentido estrito, há características comuns, que podem ser o ponto de partida para a boa convivência, o respeito, a amizade e a empatia. Quando não se enxerga a si mesmo no outro, a convivência é impossível. A lição de Francisco de Vitória continua atual, mas, muitas vezes, negligenciada por interesses egoístas.

Vitória é um grande representante da Era de Ouro na Espanha e lança bases importantes para o projeto de construção dos direitos humanos. Sua atuação na construção do Direito Internacional é citada pelo próprio 
Hugo Grotius, considerado o "pai" desse ramo jurídico, por reconhecer sua contribuição para a discussão da justiça das guerras coloniais e religiosas e para a delimitação da jurisdição do Estado e da Igreja.

Por fim, vale frisar que, se o ocidente é sempre acusado, de maneira reducionista, de não respeitar a diferença, deve ser dito que, apesar das várias atrocidades cometidas com o outro, a reflexão sobre a alteridade é uma preocupação da cultura ocidental através do seu arcabouço teórico. Por isso, retomar um autor do século XVI faz parte da busca pela reflexão da alteridade na cidade.

\section{REFERÊNCIAS}

AGUIAR, Roberto A. R. Alteridade e rede no direito. Veredas do Direito, Belo Horizonte, v. 3, n. 6, p. 11-43, jul./dez. 2006. Disponível em: $<$ http:// www.domhelder.edu.br/revista/index.php/veredas/article/view/71/54>. Acesso em: 30 abr. 2017.

ARISTÓTELES. Política: versão bilíngue. Tradução de Antônio Campelo Amaral e Carlos Gomes. Lisboa: Vega, 1998.

BÍBLIA SAGRADA: Edição Pastoral. Disponível em: <http://www.paulus. com.br/biblia-pastoral/_INDEX.HTM>. Acesso em: 30 abr. 2017.

CAENEGEM, R. C. van. Uma introdução histórica ao direito privado. Tradução de Carlos Eduardo Lima Machado. 2. ed. São Paulo: Martins Fontes, 2000. (Ensino Superior).

DE BONI, Luis Alberto. Apresentação. Veritas: Revista de Filosofia da PUCRS, Porto Alegre, v. 54, n. 3, p. 5-11, set./dez. 2009. Disponível em: $\quad<$ http://revistaseletronicas.pucrs.br/ojs/index.php/veritas/article/ view/6413/4679>. Acesso em: 30 abr. 2017.

FRANCISCO DE VITÓRIA. Sobre el poder civil. Sobre los indios. Sobre el derecho de la guerra. Estudio preliminar, traducción y notas de Luis Frayle Delgado. Comentario crítico de José-Leandro Martínez-Cardós Ruiz. Madrid: Tecnos, 2007. 
FRAYLE DELGADO, Luis. Estudio preliminar. In: FRANCISCO DE VITÓRIA. Sobre el poder civil. Sobre los indios. Sobre el derecho de la guerra. Madrid: Tecnos, 2007, p. IX-XXXV.

GROTIUS, Hugo. The rights of war and peace. From the edition by Jean Barbeyrac. Indianapolis: Liberty Fund, 2005.

MORA HERNÁNDEZ, Carlos Bretón. Los derechos humanos en Francisco de Vitória. En-claves del pensamiento, Ciudad de México, año VII, núm. 14, pp. 35-62, jul.-dic. 2013. Disponível em: <http://www.redalyc. org/pdf/1411/141128984002.pdf>. Acesso em: 30 abr. 2017.

PÉREZ, José Luis. A questão ética da responsabilidade: um itinerário pela contemporaneidade. In: BECKERT, Cristina et al (Coords.). Ética: teoria e prática. Lisboa: Centro de Filosofia da Universidade de Lisboa, 2012, p. 305-322.

PÉREZ LUÑO, Antonio Enrique. Derechos humanos, estado de derecho y constitución. 6. ed. Madrid: Tecnos, 1999.

PÉREZ LUÑO, Antonio-Enrique. La universalidad de los derechos humanos. Anuario de filosofía del derecho, Madrid, t. 15, p. 95-110, 1998. Disponível em: <https://www.boe.es/publicaciones/anuarios_derecho/abrir_pdf.php?id=ANU-F-1998-10009500110_ANUARIO_DE_ FILOSOF\%26\%23833\%3B_DEL_DERECHO_Sobre_la_universalidad_ de_los_derechos_humanos $>$. Acesso em: 30 abr. 2017.

PICH, Roberto Hofmeister. Dominium e Ius: sobre a fundamentação dos direitos humanos segundo Francisco de Vitoria (1483-1546). Teocomunicação, Porto Alegre, v. 42, n. 2, p. 376-401, jul./dez. 2012.

RUIZ, José-Leandro Martínez-Cardós. Comentario crítico. In: FRANCISCO DE VITÓRIA. Sobre el poder civil. Sobre los indios. Sobre el derecho de la guerra. Madrid: Tecnos, 2007, p. XXXVII-LXXXI.

SALES, Antônio Patativa de. Bartolomé de las Casas e Francisco de Vitoria: filosofia política e moral no debate sobre o direito natural e o direito das gentes no Novo Mundo. Protestantismo em Revista, São Leopoldo, v. 
28, p. 52-59, maio/ago. 2012. Disponível em: <http://periodicos.est.edu. br/index.php/nepp/article/viewFile/219/349>. Acesso em: 30 abr. 2017.

SARTRE, Jean-Paul. O existencialismo é um humanismo. In: MARÇAL, Jairo (Org.). Antologia de textos filosóficos. Curitiba: SEEDPR, 2009, p. 616-639. Disponível em: <http://www.educadores.diaadia.pr.gov.br/arquivos/File/cadernos_pedagogicos/caderno_filo.pdf $>$. Acesso em: 30 abr. 2017.

SARTRE, Jean-Paul. O ser e o nada: ensaio de ontologia fenomenológica. 15. ed. Tradução de Paulo Perdigão. Petrópolis, RJ: Vozes, 2007.

SCATTOLA, Merio. Domingo de Soto e la fondazione della Scuola di Salamanca. Veritas: Revista de Filosofia da PUCRS, Porto Alegre, v. 54, n. 3, p. 52-70, set./dez. 2009. Disponível em: $<$ http://revistaseletronicas. pucrs.br/ojs/index.php/veritas/article/view/6413/4679>. Acesso em: 30 abr. 2017.

ULLMANN, Reinholdo Aloysio. A universidade medieval. Porto Alegre: EDIPUCRS, 2000.

URDANOZ, Teofilo. Las Casas y Francisco de Vitoria (En el V centenario del nacimiento de Bartolomé de Las Casas, 1474-1974). Revista de Estudios Políticos, Madrid, n. 198, p. 115-191, Nov./Dic. 1974.

Artigo recebido em: 24/05/2017.

Artigo aceito em: 28/08/2017.

\section{Como citar este artigo (ABNT):}

REIS, Émilien Vilas Boas; NAVES, Bruno Torquato de Oliveira. O Nascimento do Direito à Alteridade na Cidade. Veredas do Direito, Belo Horizonte, v. 14, n. 29, p. 55-79, mai./ago. 2017. Disponível em: <http://www. domhelder.edu.br/revista/index.php/veredas/article/view/1071>. Acesso em: dia mês. ano. 